Supporting information:

\title{
Biological Denitrification In Microbial Fuel Cells
}

Peter Clauwaert, Korneel Rabaey, Peter Aelterman, Liesje De Schamphelaire, The Hai Pham, Pascal Boeckx, Nico Boon and Willy Verstraete

\section{Summary:}

Page S2: Figure S1

Page S3: Figure S2

Page S4: Figure S3

Page S5: Microbial community analysis \& Figure S4 


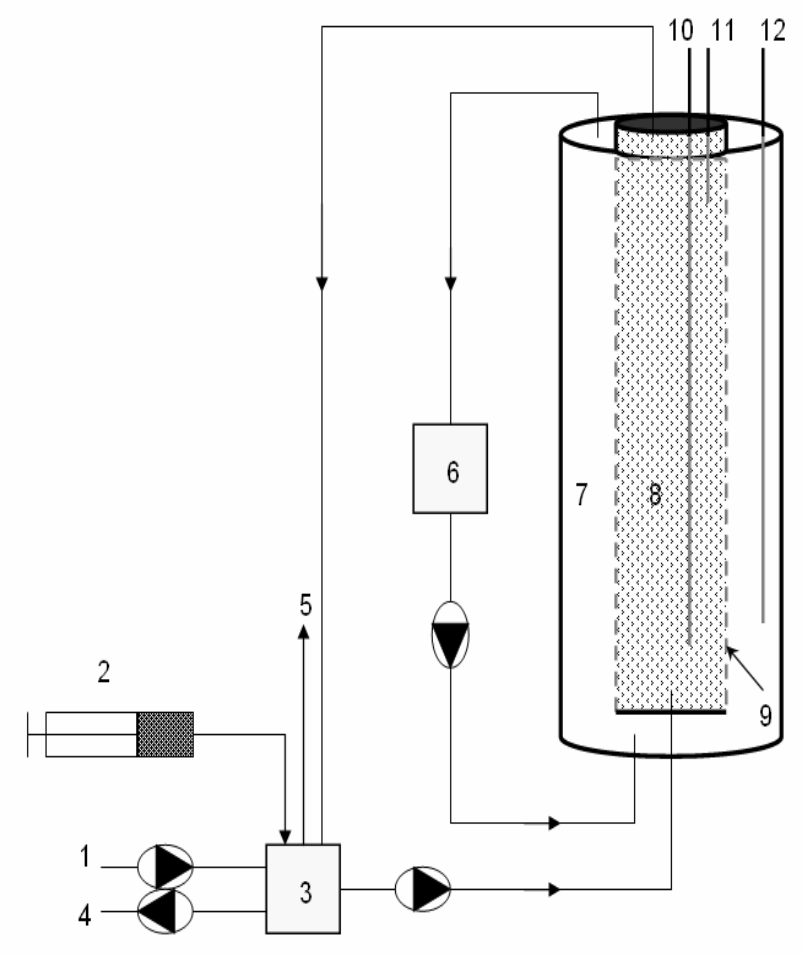

Figure S1: Schematic overview of the experimental set-up (1: influent, 2: syringe with a $2.615 \mathrm{~g} \mathrm{NO}_{3}^{-}-\mathrm{N} \mathrm{L}^{-1}$ solution, 3: cathodic recirculation vessel, 4: effluent, 5: gas collector, 6: anodic recirculation vessel, 7: anodic compartment, 8: cathodic compartment, 9: cation exchange membrane, 10: cathodic electrode, 11: reference electrode, 12: anodic electrode) 


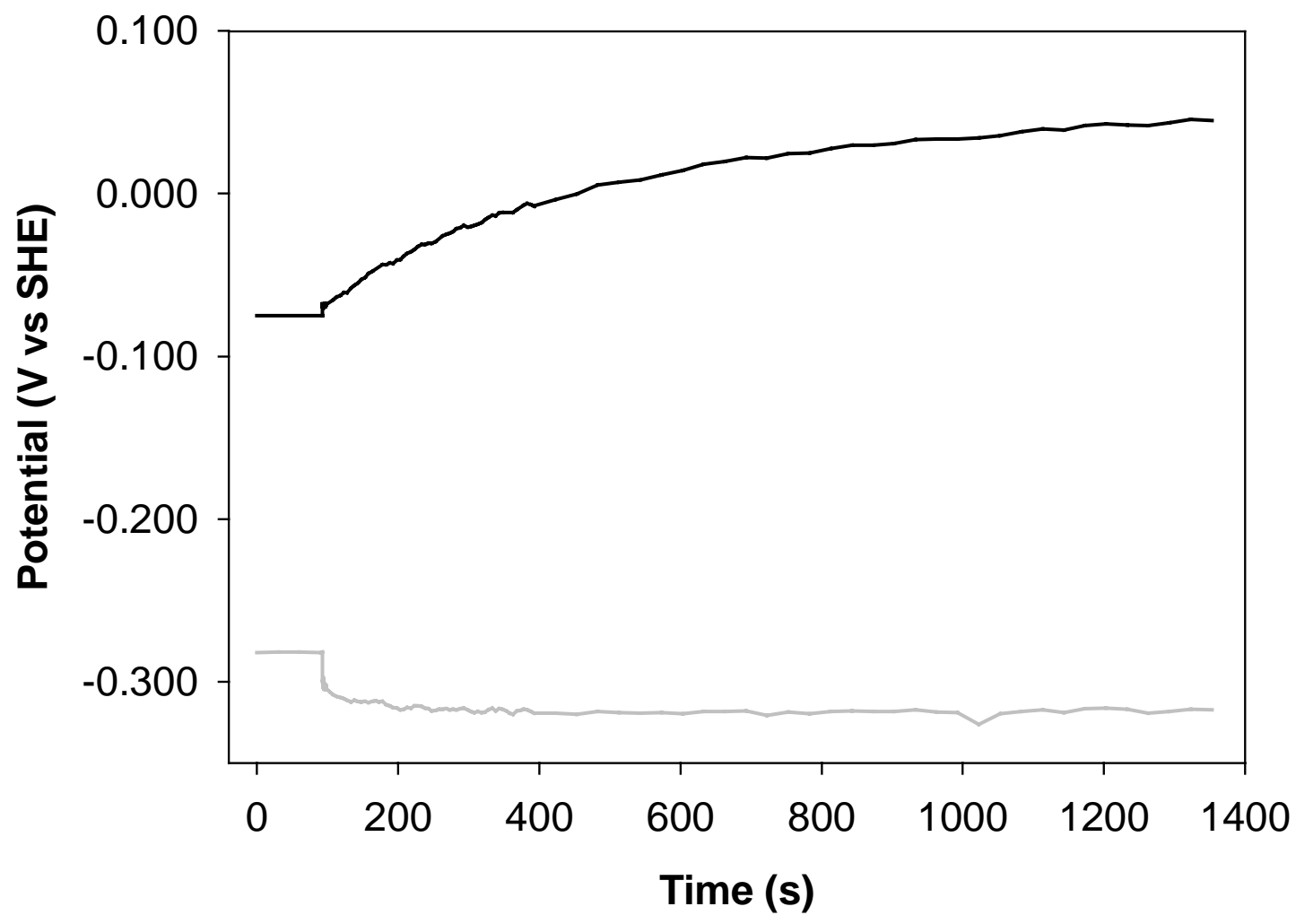

Figure S2: Potential of the cathodic ( - ) and the counter ( - ) electrode during a current interrupt experiment to determine the ohmic resistance (before the current interrupt a fixed cathodic redox potential of $-0.075 \mathrm{~V}$ vs SHE was controlled resulting in a current production of $16 \mathrm{~A} \mathrm{~m}^{-3} \mathrm{NCC}$ ) 


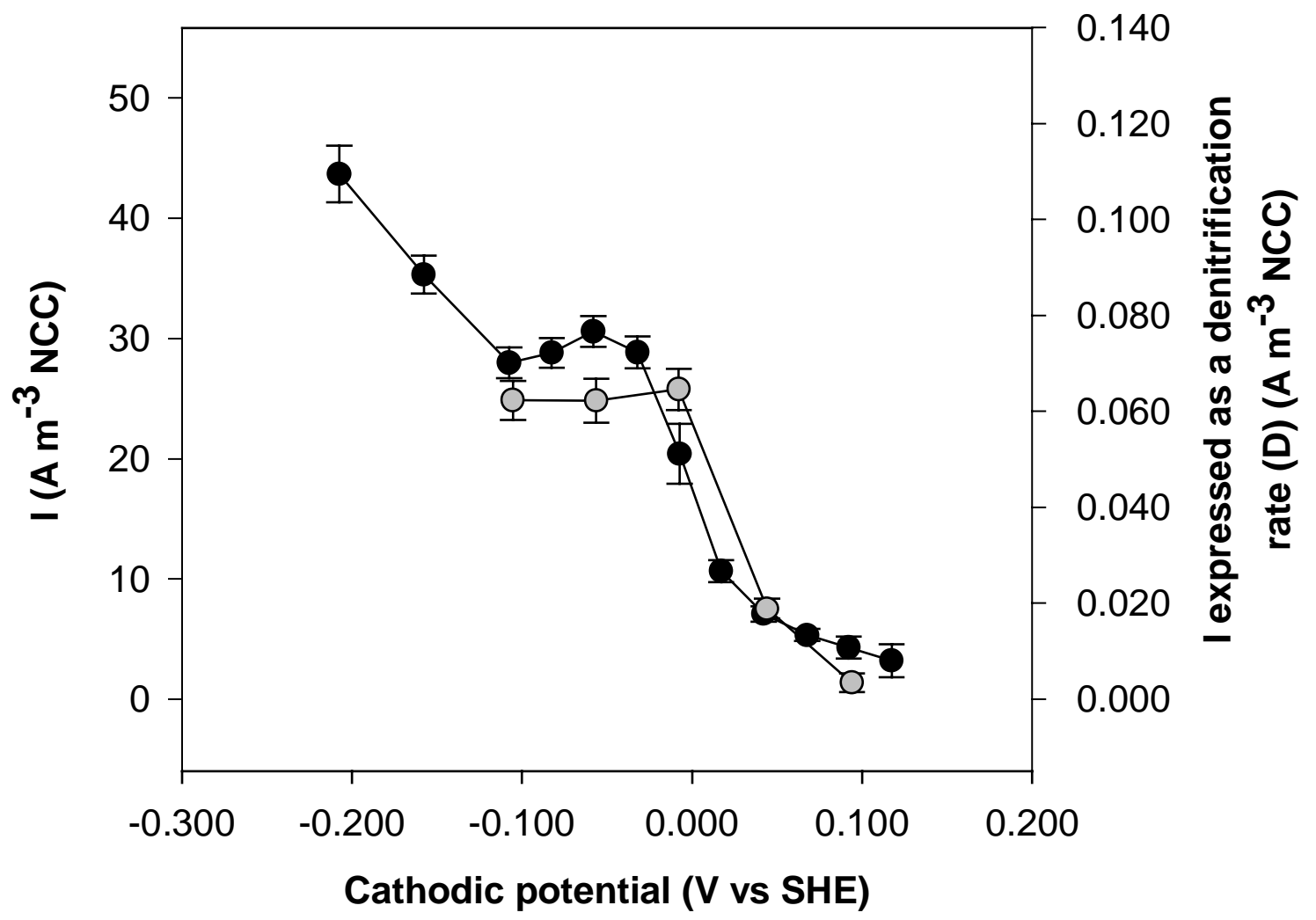

Figure S3: The average current production at a poised cathodic potential ; from a high to a low potential tested at two nitrate loading rates $\left(0: 0.096 \mathrm{~kg} \mathrm{~N} \mathrm{~m}^{-3}\right.$ $\left.N C C \mathrm{~d}^{-1} ; \bigcirc: 0.075 \mathrm{~kg} \mathrm{~N} \mathrm{~m}^{-3} \mathrm{NCC} \mathrm{d}^{-1}\right)$ 
Microbial community analysis. $500 \mathrm{~mL}$ effluent from both denitrifying cathodic systems was filtered and total DNA extraction from the biomass samples and PCR conditions were based on the protocols described previously (31). The 16S rRNA genes for all Bacteria were amplified by PCR using the forward primer P338F and the reverse primer P518r and a GC-clamp of $40 \mathrm{bp}$ was added to the forward primer. Polymerase Chain Reaction Denaturing Gradient Gel Electrophoresis (PCR-DGGE) was done as described previously (32). The normalization and analysis of DGGE gel patterns was done with the BioNumerics 9 software 2.0 (Applied Maths, Kortrijk, Belgium). The calculation of the matrix of similarities between the two DGGE patterns is based on the Pearson product-moment correlation coefficient and was $71.6 \%$ in this case.

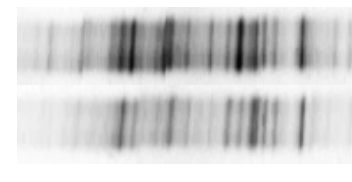

K1

K2

Figure S4 : The DGGE pattern of the effluent of both denitrifying cathodes (K1 \& K2) 